\title{
PHARMACY
}

\section{SCIENTIFIC COMPREHENSION OF THE NECESSITY OF PHARMACEUTICAL TOURISM DEVELOPMENT IN UKRAINE AND THE RESEARCH OF ORGANIZATIONAL AND ECONOMIC APPROACHES AS TO ITS IMPLEMENTATION IN THE HEALTHCARE SYSTEM}

\author{
O. S. Samborskyi, Candidate of Pharmacy, Associate Professor, Ivano-Frankivsk National Medical \\ University, Department of Organization and Economics of Pharmacy and Drug Technology, Ivano- \\ Frankivsk, Ukraine, ORCID ID: http://orcid.org/0000-0002-8913-0965
}

\begin{abstract}
M. M. Slobodyanyuk, Doctor of Pharmacy, Professor, National Pharmaceutical University, Department of Pharmaceutical Marketing and Management, Kharkiv, Ukraine, ORCID ID: http://orcid.org/0000-0001-9328-0539
\end{abstract}

\section{O. Y. Rogulya, Candidate of Pharmacy, Associate Professor, National Pharmaceutical University, Department of Pharmaceutical Marketing and Management, Kharkiv, Ukraine,} ORCID ID: http://orcid.org/0000-0001-5065-4545

\section{DOI: https://doi.org/10.31435/rsglobal_ws/31052020/7079}

\section{ARTICLE INFO}

Received: 10 March 2020

Accepted: 12 May 2020

Published: 31 May 2020

\section{KEYWORDS}

medical tourism,

social and economic accessibility of drugs,

pharmaceutical tourism, physical accessibility of drugs.

\begin{abstract}
The article proved that pharmaceutical tourism has been developed during a long period of time as an essen-tial part of medical tourism. The defined forms of activity have an integral character and contribute to the in-crease of the level of accessibility and quality of medical and pharmaceutical aid to the population outside their regular place of residence. The preconditions for activation the development of medical tourism and the necessity of being regarded as an independent activity of pharmaceutical tourism have been determined. In-stitutional components of pharmaceutical tourism (a subject, objects, subjects, forms of organization) have been outlined and described as well as the functions, which can be used on two levels: on the level of the government and the society, and in the system of pharmaceutical provision of the population and healthcare in general. The integral and dualistic character of pharmaceutical tourism as a modern activity in the system of healthcare has been substantiated. Taking into account modern tendencies as to globalization of national economics, imperfection of mechanisms of government regulation of the level of accessibility of pharmaceu-tical aid, increase of gap between different countries, groups of population or patients in the resource provi-sion of national systems of healthcare, the need for the development of medical and pharmaceutical tourism will continue in the future. It promotes the development of a complex program of their implementation in Ukraine.
\end{abstract}

Citation: O. S. Samborskyi, M. M. Slobodyanyuk, O. Y. Rogulya. (2020) Scientific Comprehension of the Necessity of Pharmaceutical Tourism Development in Ukraine and the Research of Organizational and Economic Approaches as to Its Implementation in the Healthcare System. World Science. 5(57), Vol.2. doi: 10.31435/rsglobal_ws/31052020/7079

Copyright: (C) 2020 O. S. Samborskyi, M. M. Slobodyanyuk, O. Y. Rogulya. This is an open-access article distributed under the terms of the Creative Commons Attribution License (CC BY). The use, distribution or reproduction in other forums is permitted, provided the original author(s) or licensor are credited and that the original publication in this journal is cited, in accordance with accepted academic practice. No use, distribution or reproduction is permitted which does not comply with these terms. 
Introduction. At the end of the last century, the processes of globalization have been consolidated almost in all spheres of social and economic activity of the society. A Healthcare System is not an exception. The availability and dialectic development of two tendencies - integration and fragmentation resulted in the appearance of new forms and methods of organization of medical and pharmaceutical aid for the population and the appropriate services as well in the national Healthcare System. One of these innovative forms is organization of medical tourism, which is characterized by a set of measures aimed at providing medical services for the population outside their regular place of residence, including the country, where they live.

Pharmacies, as active subjects of economic relations in these processes, have not been put aside. Since the late of 1990s, most countries of the world faced up with huge changes in the relation of the government and the society to the function of pharmacists and pharmacies as to the provision of efficient services. The concept "pharmaceutical aid", further on referred to as "pharmaceutical services" came into use and was fixed in the appropriate legal regulations. Otherwise, pharmacies and pharmacists have not been regarded as inactive components in the formation of efficient relations in Healthcare System any more. At present, under the condition of the growth of pharmaceutical market and the increase of tendencies as to commercialization in the Healthcare System, specifically in pharmacies while providing services, pharmacists solve the most actual problems, which deal with the formation of the level of accessibility of the population to efficient drugs as regulators of relations between the consumers, drugs manufacturers, pharmacies. Under these conditions, the issue of providing pharmaceutical aid and pharmaceutical services to people, who are temporarily residing in Ukraine, needs to be regarded in order to get a complex of recreational or therapeutic diagnostic and therapeutic cosmetic, dental services. The issue of legal, regulatory, organizational and economic improvement of medical tourism organization as well as the problem of buying drugs by the Ukrainians abroad and by the foreigners at the territory of Ukraine (Transcarpathian region, IvanoFrankivsk region, Chernivtsi and Volyn regions) is becoming more and more actual. Thus, for these western regions of Ukraine the problem of increasing the volume of efficient medical and pharmaceutical services to foreigners, according to the programs of group or individual tourism, has an important economic value, first of all, for their regular development. Moreover, taking into account the traditions of relative and ethno-cultural communication of people residing in the above-mentioned regions with representatives of the neighboring eastern European countries, organization of medical tourism and provision of efficient pharmaceutical services have a social value as well. Thus, one can state that during the last years there have formed objective conditions for scientific substantiation of organizational and economic approaches to the implementation of pharmaceutical tourism in Healthcare System. The above-stated information determined the main goal of the research.

The goal of the research is to comprehend the necessity of growth and to develop organizational and economic approaches of functioning of pharmaceutical tourism in the national Healthcare System as a modern and integral form of activity, which is focused on increasing the level of physical and social economic accessibility of drugs and a number of services, which are provided in pharmacies of different forms of property and economy.

Materials and methods of research. In order to achieve the goal efficiently, we have developed the following tasks of research: to characterize medical tourism as a set of measures for increasing the level of accessibility of medical aid and medical services, and recreational services to people in different countries of the world as well, to determine the preconditions of medical tourism active development in the context of globalization of different forms of activity and cooperation in the world, to outline preconditions of separation of pharmaceutical tourism as to taking measures for organization of medical tourism, to develop and to propose a complex of organizational and economic approaches as to efficient implementation of pharmaceutical tourism in the national HS.

The objects of the research were the data taken from references, in which the following issues were revealed: organization of medical tourism, disproportion in government insurance of accessibility of pharmaceutical aid and drugs, particularly in the formation and regulation of retail prices in different countries of the world, analysis of problems and perspectives of implementation of measures as to increasing the level of medical aid and pharmaceutical aid in the countries, which borders with each other, and in those countries, which have a highly-developed medical and pharmaceutical structure and qualified specialists in particular. The calculation of the average price for the drug, according to which a comparison with similar indexes has been delivered in other countries using the data of the analytical research system of pharmaceutical market «PharmXplorer»/ «Pharmstandard» 
(«Proxima Research» Company) during 2012-2019. All indexes required have been processed with the help of a standard set of statistical analysis Statistica (version 12.0, StatSoft, Tulsa, USA).

During the research, we have used a systematic approach and historical, logical, comparative, graphic and other methods of scientific research and cognition.

Results and discussion. Despite of the significant efforts of governments of different countries and international organizations like the World Organization of Health Protection (WOHP), it is impossible to overcome a threatening tendency towards the increase of the gap between the volume and the level of governmental and social guarantees in providing accessible pharmaceutical aid and pharmaceutical services in different countries now. Ukraine is not an exception in this list, which only begins to use models of socially-oriented relations between people, government and social institutions on the way of increasing the level of accessibility of the appropriate services in Healthcare System.

As a result of the development of the above-mentioned tendencies, medical tourism is being regarded as a socially-important and an integral form of activity, which became an alternative for some spheres of the population on the way to overcoming a low level of accessibility or quality of pharmaceutical aid and pharmaceutical services.

Classical definition of medical tourism means a set of measures directed on increasing the level of meeting the needs of the population in providing efficient (qualitative, accessible and rational) pharmaceutical aid and pharmaceutical services to the consumers outside their regular place of residence [1-3]. The history of development of medical tourism begins from IX century, when representatives of wealthy layers of the society went to the world recreational resorts located mostly in Europe [4,5]. Some scientists consider that medical tourism specifically is the oldest form of tourism $[3,6,7]$. By the estimation of specialists, medical tourism, as a separate form of activity, which has characteristics of symbiosis of medical, pharmaceutical, tourist, cultural and social components of tourism, was finally formed at the beginning of the 1980s [3, 5-7].

The need of a person to save his life, on the level, which meets up-to-date requirements, is one of the basic social categories, which make up the main postulates of the country modern development. A free option of different medical manipulations, institutions, specialists and procedures is clearly defined in the European Charter on Patients Rights (2002), which should be used according to the relevant information. Efficient implementation of this right is ensured by providing services in the sphere of medical tourism [5].

Under the conditions of active development of the society, scientific and technical progress and tendencies towards the humanization of the society, the demands of the population as to healthcare on a qualitative level are growing by going ahead financial situation of the society and government institutions in all spheres of the society, without exception. At the end of the last decade of the last century, there has appeared a need of some groups of the population, which have been characterized by a low level of income as well as patients of some groups, for the increase of the level of accessibility of pharmaceutical aid and pharmaceutical services $[1,8,9]$. The index of accessibility of the appropriate services for ordinary people is gradually transforming from the category of special in Healthcare System to socially-important ones.

Medical tourism, as an integral form of activity in Healthcare System, is characterized by a significant potential of development. Thus, for example, in 2012 the sales volume of marketing tourism was evaluated by the specialists as 10.5 billiard USD (do not taking into account transportation expenses for crossing the border and getting to the place of treatment), and in 2019 the above-stated index increased up to 32.5 billiard UDS, that is by 3 times [6,10]. In the global dimension, we can single out a number of the most powerful clusters of marketing tourism development: Southern-Western Asia, United Arab Emirates (Dubai), countries of European Union and Great Britain, USA and Canada, Mexico, India, Pakistan and Turkey, China $[6,9,10]$.

By the official data, in 2018 with the purpose of getting recreational services, around 65 thousand medical tourists visited Ukraine. By the economists' calculations, the average price for medical, pharmaceutical aid and services provided by the marketing tourism programs amounted to 2.5 thousand USD, and the income earned was approximately 162 million USD [11]. Income earned by the entrepreneurs after providing different services (hotel accommodation, hospice accommodation, excursions, catering, etc.) was approximately 60 million USD. According to the data, in 2018 the city of Truskavets (Lviv region) hosted approximately 40 thousand foreigners, $40.0 \%$ of them were from Poland [11]. It is worth mentioning that the peculiarity of marketing tourism in Ukrainian realities is a significant domination of medical tourists, who entered the country to improve their health over the number of people, who received recreational services. Thus, in Ukraine recreational form of marketing tourism prevails considerably over its therapeutic and diagnostic form. 
By the results of systematization of data taken from references, we have outlined the preconditions of activation of different forms of marketing tourism at the junction of XIX-XX centuries, and also we have submitted the results of systematization of data taken from references according to the given subject area. Herewith, it is worth mentioning that in national infosphere there isn't any works, which contain issues of medical tourism and also organization of pharmaceutical tourism, have been regarded as integral forms of activity in Healthcare System, the main trend of realization of which is the increase of the level of accessibility and quality of pharmaceutical aid and pharmaceutical services. As we see in Table 1, for a qualitative evaluation of functioning efficiency, Medical Tourism Index (MTI) is used.

Table 1 . Characteristics of medical tourism as an integral form of activity under the conditions of increasing a tendency towards world globalization

\begin{tabular}{|c|c|}
\hline \multicolumn{2}{|c|}{$\begin{array}{c}\text { Parameters of marketing tourism analysis } \\
\end{array}$} \\
\hline \multicolumn{2}{|c|}{ Results of analysis according to the parameters of the analysis provided } \\
\hline \multicolumn{2}{|c|}{ Preconditions of active development at the junction of $X I X-X X$ centuries } \\
\hline \multirow{10}{*}{\multicolumn{2}{|c|}{ 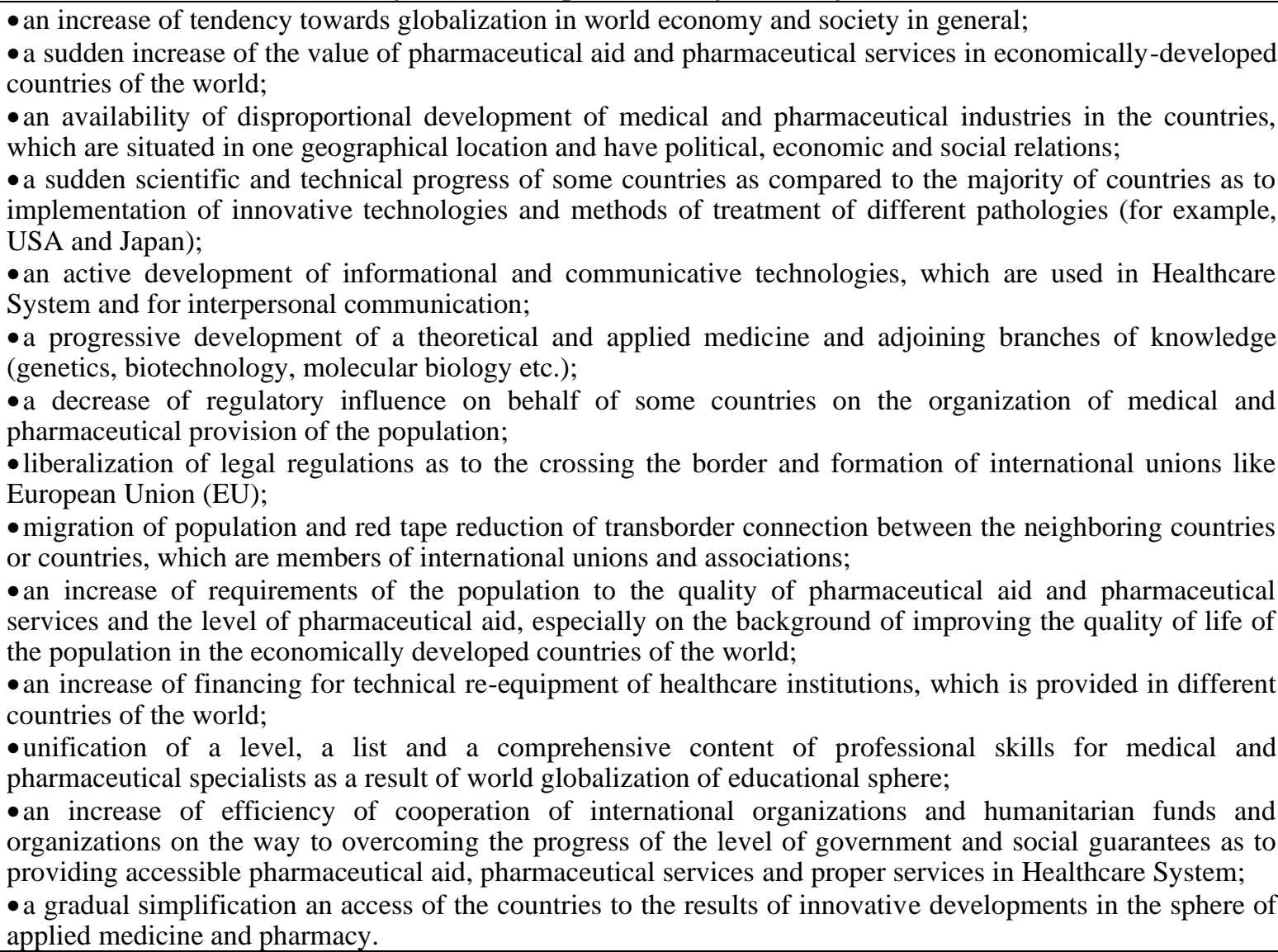 }} \\
\hline & \\
\hline & \\
\hline & \\
\hline & \\
\hline & \\
\hline & \\
\hline & \\
\hline & \\
\hline & \\
\hline \multicolumn{2}{|c|}{ Trends of realization } \\
\hline \multicolumn{2}{|c|}{$\begin{array}{l}\text { - consumers of pharmaceutical aid and pharmaceutical services from economically developed countries come } \\
\text { to the countries with a lower economic level in order to get proper aid for lower prices or by the current time- } \\
\text { table of providing services; } \\
\text { o consumers of medical and pharmaceutical services from the countries, which do not have proposals of } \\
\text { highly-qualified or field-specific pharmaceutical aid and pharmaceutical services, and the names of drugs are } \\
\text { provided to the countries, which are characterized by the availability of innovative methods and procedures of } \\
\text { treatment, for example, heavy, chronic, orphan pathologies etc. }\end{array}$} \\
\hline \\
\hline character & Trend \\
\hline & \\
\hline
\end{tabular}


Continuation of table 1 .

\begin{tabular}{|c|c|}
\hline Ch & \\
\hline $\begin{array}{l}\text { - therapeutic-diagnostic; } \\
\text { - dental; } \\
\text { - incurable; } \\
\text { - recreational; } \\
\text { - therapeutic-recreational; } \\
\text { - therapeutic-cosmetic; } \\
\text { - reproductive; } \\
\text { - orthopedic; } \\
\text { - organization of euthanasia; } \\
\text { - organization of plastic correct } \\
\text { appearance; } \\
\text { - organization of gender change }\end{array}$ & $\begin{array}{l}\text { - centralized (organization of medical tourism } \\
\text { by travel, insurance companies, humanitarian or } \\
\text { other public organizations, and also by the } \\
\text { employer within the fulfillment of obligations } \\
\text { stipulated in agreements or contracts); } \\
\text { - decentralized (individual organization of } \\
\text { medical tourism on behalf of a physical entity or } \\
\text { a group of people) }\end{array}$ \\
\hline \multicolumn{2}{|c|}{ Quality indexes of medical tourism efficiency evaluation } \\
\hline \multicolumn{2}{|c|}{$\begin{array}{l}\text { International Healthcare Research Center proposed «Medical Tourism Index - MTI) for some countries of the } \\
\text { world [8]. To define MTI they have used four groups of indexes. I group (the environment and general } \\
\text { characteristics of countries, for example, factors like availability of regular national currency exchange rate } \\
\text { according to world currency or currency of neighboring countries, cultural and ethno-lingual similarity, level } \\
\text { of crime in the country etc). II group (availability and level of development of travel infrastructure in the } \\
\text { country). III group (price indexes, which allow to evaluate level of pharmaceutical aid and pharmaceutical } \\
\text { aid, evaluation of opportunity of their reduction). IV group (the condition of organization of pharmaceutical } \\
\text { aid and pharmaceutical aid, availability of certified medical and pharmaceutical staff by international } \\
\text { standards, and level of reputation of healthcare institutions and pharmacies, their accreditation, inventory of } \\
\text { these institutions and their provision etc. [8]. }\end{array}$} \\
\hline
\end{tabular}

Top-25 countries with the highest MTI indexes for medical tourists include 7 countries of Asia: Singapore (index 74.0\%), Philippines (70.7\%), Japan (70.2\%), Korea Republic (70\%), India $(67.5 \%)$, Thailand $(65.5 \%)$ and China $(63.1 \%)$ [8,14]. In 2015 at least 439 healthcare institutions of Asian region were accredited by the Company «dJoint Commission Internationalt» [5,18]. In 2015 at least 439 healthcare institutions in the countries of Asian region were accredited by the Company «dJoint Commission Internationalt» $[6,10]$.

Taking into account strengthening of the world tendency to globalization, to our mind, marketing tourism will continue to develop by a wide sphere of trends and to make a greater influence on the level of accessibility and quality of pharmaceutical aid and pharmaceutical aid to the population. Thus, there have been certain changes in the organization of medical tourism as to the separation of pharmaceutical tourism as an individual integral activity.

According to the analysis of references, one can state that due to the absence of a clear definition of the notion "medical tourism", the notion "pharmaceutical tourism" is used in most researches as a constituent part in the organization of measures for providing pharmaceutical aid and pharmaceutical services to people outside their regular place of residence [3,4,12]. Buying drugs abroad is regarded as an important constituent part in the process of realization of medical tourism to people. Firstly, the problem of pharmaceutical provision of people living abroad was reviewed as an analysis of quality of different drugs, which were purchased by the consumers abroad, for example, in Mexico [13,14]. Some researches are dedicated to the analysis of the price attraction of some names of drugs and opportunities to increase the accessibility of different layers of socially vulnerable groups of the population and categories of patients to drugs $[3,5,7,10]$. In some publications, the authors use the notion "pharmaceutical tourism", but they do not give its definition and consider it as a constituent part of the process of medical tourism realization $[12,13]$.

In classical definition, drugs accessibility is a complex category, which should be regarded in two aspects - physical and social-economic $[1,16]$. According to the defined characteristics of drugs accessibility, we can single out the main preconditions for regarding pharmaceutical tourism as an individual notional category.

Social-economic accessibility of drugs. Efficient realization of principles of equal access of people to the main essential drugs, in modern realities of development of a society of economically developed countries, is regarded as an important, but not the only problem $[17,18]$. Now in many healthcare institutions of different countries we observe a gradual transition to the model of sociallyoriented access to the drugs required for a certain person. Individualized medicine, development of the "family pharmacist" institute, permanent increase of demands of the society to efficient 
pharmaceutical aid and pharmaceutical services contributed to further complication of mechanisms of government regulation of prices for drugs within the whole commodity-distribution network of their promotion on a pharmaceutical market. Therefore, availability of significant disproportions in the level of price regulation for the internal pharmaceutical markets of different countries, especially which border with each other, is one of the most important factors of pharmaceutical tourism development. Moreover, existing of a complicated, in some cases top-heavy system of price regulation on the internal pharmaceutical market, requires the consumers of pharmaceutical services to make decisions on buying drugs abroad. Firstly, such decisions are made situationally, and then they require implementation of a complex evaluation and programs in organization of pharmaceutical tourism for the population. Availability of essential difference in retail prices for brand names of drugs in the neighboring countries is well-known to Ukrainians, who are residing in Western regions of our country. Thus, residents of the regions of Ukraine, which border with Poland, travel there to buy drugs prescribed by Ukrainian doctors, and they also order drugs in Internet-pharmacies [19,20]. As travel agents state, one more country, where Ukrainians purchase drugs in a large quantities while travelling is Turkey [7,10]. On Figures 1, 2 and 3 you can see the results of analysis of the average retail price of three brand names of drugs in 10-11 reference countries of the world, including Ukraine [21].

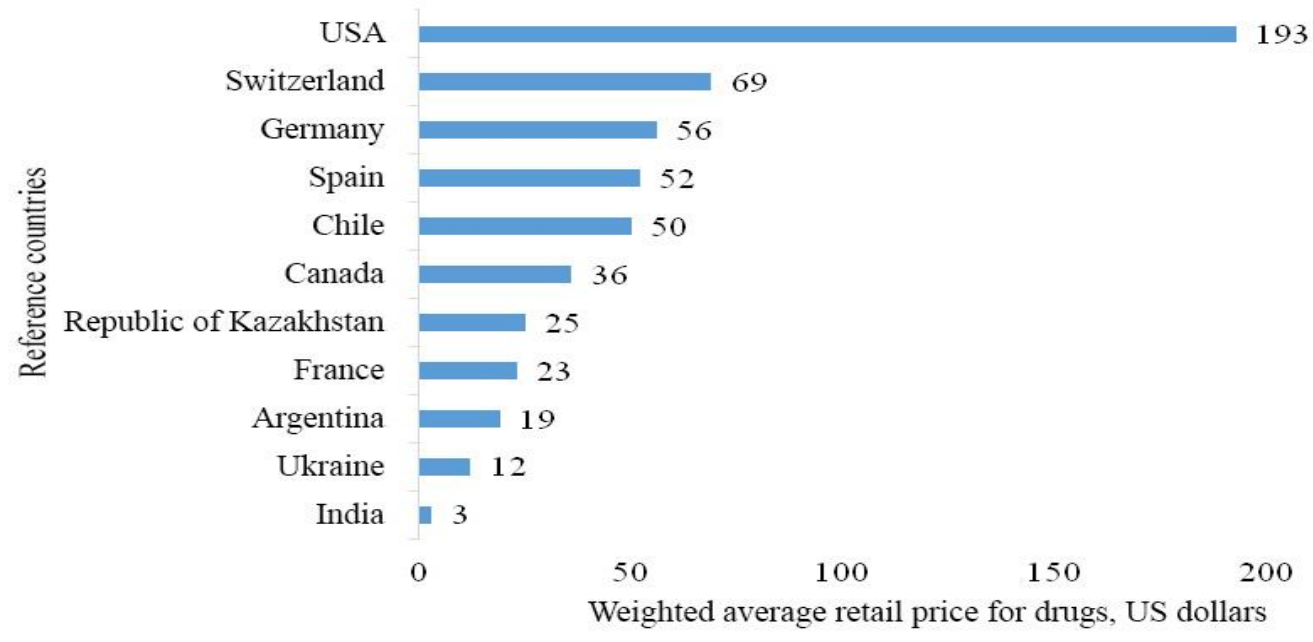

Fig. 1. Results of comparative analysis of average retail prices for Nexium $40 \mathrm{mg}$ №14 produced by «AstraZeneka» Company

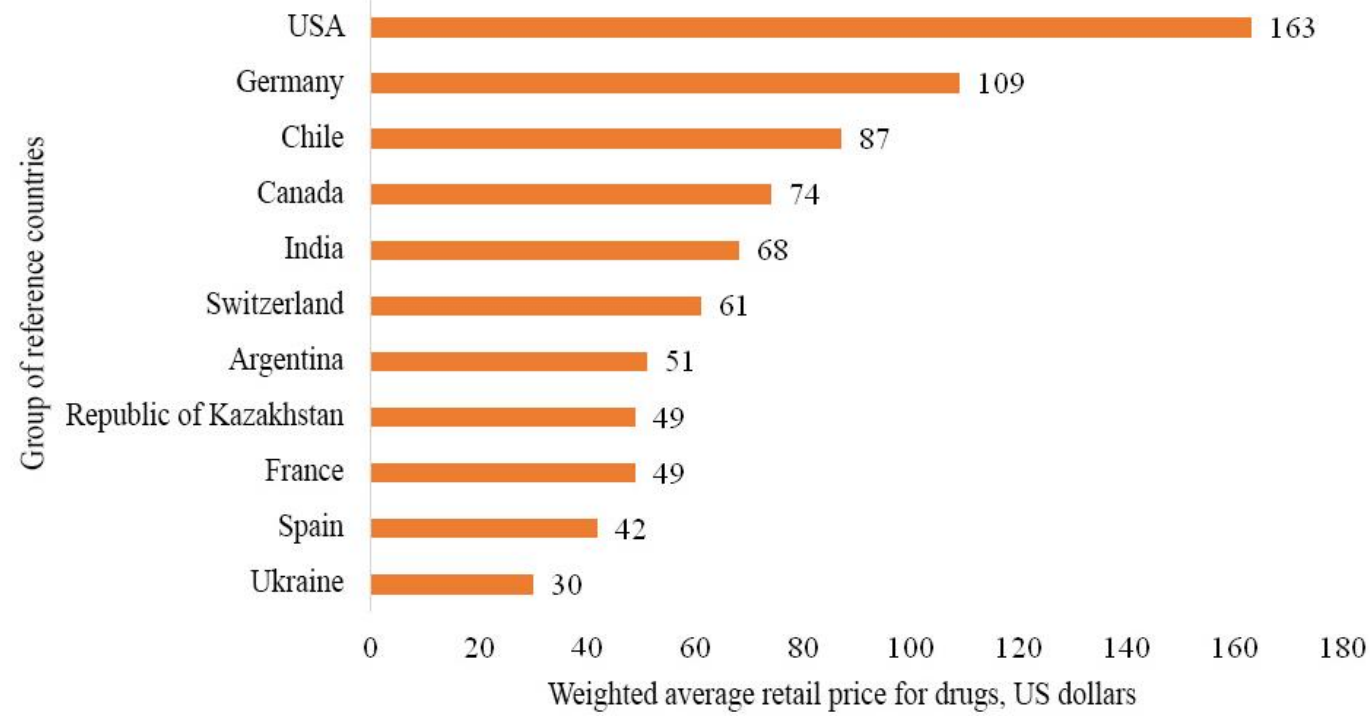

Fig. 2. Results of comparative analysis of average retail prices for Plavix, pills, $75 \mathrm{mg}$ № 28 produced by «Sanofi» Company 


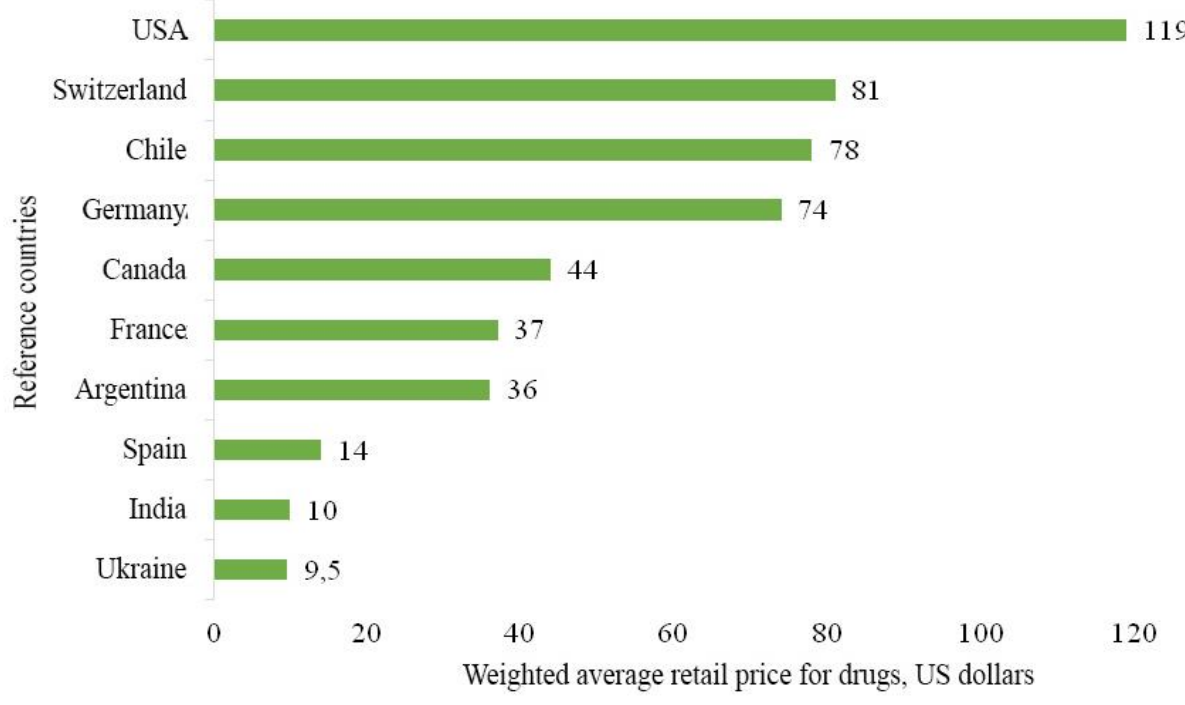

Fig. 3. Results of comparative analysis if average retail prices for Lipitor 20 MG №30 produced by «Pfiser» Company

These are drugs like Nexium 40 mg №14 produced by «AcstraZeneka» Company, Plavix, pills covered by the tape, $75 \mathrm{mg}$ №28 «Sanofi» and Lipitor $20 \mathrm{MG}$ №30 produced by «Pfiser» Company. As we see, retail price for Nexium varies in a wide range of numbers from 3.0 (India) to 193.0 USD in the USA, that is by 64.3 times. The average retail price for Plavix was from 30.0 USD in Ukraine to 163.0 USD in USA (the difference by 5.4 times), and the index of variation amounted to 133 USD. The average retail price for the last drug researched varied from 9.5 USD (Ukraine) to 119.0 USD, which means that the above-stated index differed in reference countries by 12.5 times. As we see, peculiarities of pricing policy for drugs and their government regulation influence significantly on the indexes of social-economic accessibility of drugs at all stages of goods-distribution network at the pharmaceutical market.

Global pharmaceutical market differs by a significant segmentation of geographical areas of development. At present, we can determine peculiarities of both the approaches to pricing policy and regulation of prices for drugs and the formation of product mix policy, for example, at the European, Pacific-Asian, Northern-American, Latin-American and other subjects of the world pharmaceutical market.

Taking the above-mentioned into account, at the beginning of scientific-research works in the development of innovative drugs, the majority of the most powerful pharmaceutical companies made a previous evaluation of the perceptiveness of their positioning on these or those segments of global pharmaceutical market. Thus, during a long time the countries with liberal approaches as to pricing policy for drugs (USA, Japan and Southern Korea) formed powerful centers of positioning innovative names for drugs.

In 2018 the Food and Drug Administration (FDA), which coordinates all processes of registration and sale of drugs at the national pharmaceutical market of the USA, was allowed to sell 59 (100.0\%) new brand names, 42 of which $(71.0 \%)$ had been confirmed by relevant regulation authority earlier than all other countries in the world [22]. For comparison, in 2017 the above-stated index showed 46 new brand names of drugs. Experts expect that during the next five years there will be 54 new brand names of drugs at the pharmaceutical market of the USA. During 2013-2018 FDA received over 3.5 thousand of applications to register the abbreviated new drugs («Abbreviated New Drug Application» - ANDA), 677 separate molecules or medical combinations, $87.0 \%$ of which were further represented at the internal pharmaceutical market in the USA (Figure 4) [22].

Together with the American drugs market, which is oriented on the innovative developments in pharmacy and adjoining branches of knowledge (biotechnologies, genetic engineering, molecular biology etc.), there are other world markets, which are strictly regulated or are subject to a set of government measures in reimbursement of the value of drugs consumed. To the last ones we can relate the European pharmaceutical market, which differs by its complicated and powerful mechanisms of regulation of pharmaceutical policy, including pricing and reimbursement of the value of drugs. The availability the above-stated mechanisms of pricing policy regulation and drugs value reimbursement contribute to the implementation of more accessible names of drugs-generics and bio-stimulators at the pharmaceutical market. 


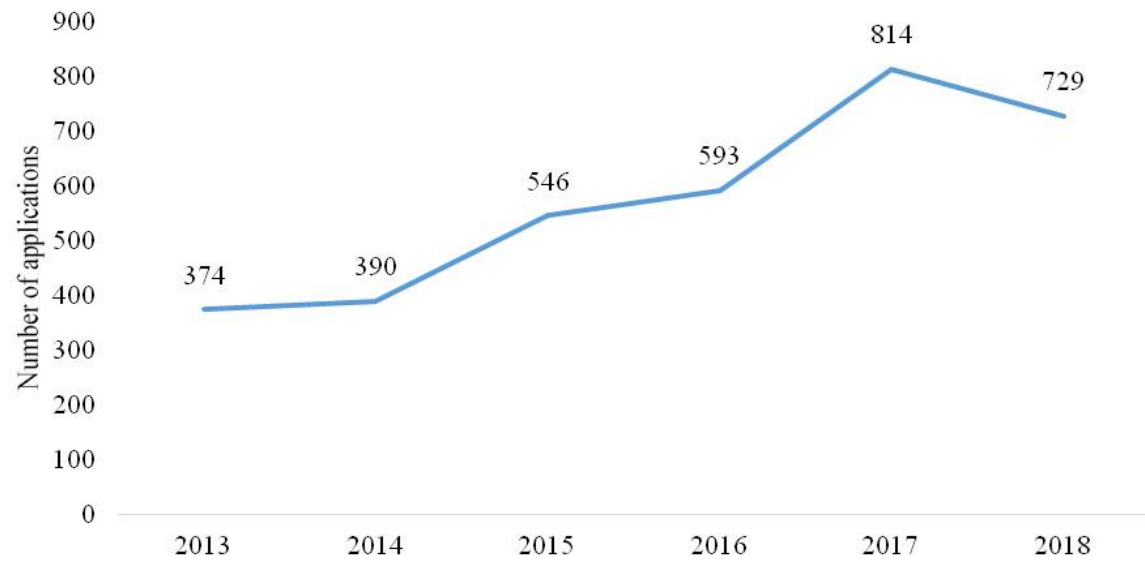

Fig. 4. Results of analysis of the number of applications for ANDA drugs-generics received by FDA during 2013-2018 in USA [22]

One of the important factors, which hold back positioning of expensive innovative drugs at the national pharmaceutical market, is a low level of credibility of population in case of absence of efficient mechanisms of regulation of accessibility of pharmaceutical aid for patients. The abovestated is observed in the countries, which are developed, first of all, in Pacific-Asian, Latin-American regions, in Northern Africa, China, India, Pakistan, former countries of USSR etc.

Peculiarities of development of some constituent parts of global pharmaceutical market demonstrate physical failure to buy essential drugs for ordinary people in those countries, where they cannot be registered without any reasons. In turn, this results in frightening cases of fraud when bringing unregistered drugs to the country and further promotion of these drugs through doubtful channels of distribution finally results in loss of health, and sometimes in loss of patients' life. The above-stated create a socially-negative profile of numerous humanitarian, volunteer and other public organizations, which do their best to provide seriously ill people with essential drugs in the country without their crossing the border.

Taking into account increase of tendency towards the growth of prices for drugs, which are sold at the internal pharmaceutical market of Ukraine, under the conditions of financial-economic crises and the absence of efficient subsystem of reimbursement of drugs, the process of purchasing drugs abroad will become more and more popular among the population. Therefore, the issue of development of pharmaceutical market in Ukraine, as a modern trend of increasing the level of accessibility of drugs and pharmaceutical aid in general in Ukraine, requires scientific comprehension and the delivery of substantial theoretically-applied research.

By arranging the results of research, first of all, thinking over the influence of modern tendencies of globalization at the world market of drugs as to the level of consumption of drugs and taking into account social importance of the increase of the level of accessibility and quality of pharmaceutical aid and a set of pharmaceutical services outside their regular place of residence, we have outlined the following preconditions for regarding pharmaceutical tourism as a new notional category paying attention on the availability of:

- disproportional development of some segments of global pharmaceutical market;

- active development of the world pharmaceutical market by the wide range of drugs - from very expensive drugs of biotechnological origin to relatively accessible generics;

- increase of tendencies towards globalization of the world pharmaceutical area and at the same time fragmentary nature of development of some constituent parts by geographical, political, social-economic, ethnic cultural and other features;

- low level of efficiency of mechanisms of government and social regulation of the level of physical and social-economic accessibility of drugs, their quality and regulation of the consumption of drugs in the countries;

- strengthening of social-humanitarian loading on pharmacies within the frames of extending the spectrum of services provided to the population;

- different by character and spectrum of influence mechanisms of regulation of pharmaceutical activity in the whole goods-distribution network of drugs promotion from idea of their development to their consumption in the countries; 
- material and social stratification of society in certain countries and the ones, which border with each other;

- increase of requirements of consumers to organization of pharmaceutical aid and pharmaceutical services under the conditions of existing resource provision of national healthcare systems;

- different approaches to pricing policy and regulation of prices at the pharmaceutical market of different countries;

- bureaucratic hurdles on the way to promotion of drugs at the internal pharmaceutical market;

- corruption risks in Healthcare System and at the pharmaceutical markets of the countries, which border with each other;

- changes in demographic structure of the population, growth of age groups of the population, which in case of having free time, can move freely within the country and outside of it in order to buy cheaper drugs and to get qualitative pharmaceutical services;

- development of international cooperation with professional pharmaceutical and consumer public organizations of different countries of the world;

- active development of modern informational-communicative technologies of both phases (medical, pharmaceutical, travel) and individual use;

- development of Internet-pharmacies and long distance forms of pharmaceutical services and a number of essential pharmaceutical services;

- active participation of employers, medical insurance companies in encouraging consumers to buy cheaper drugs outside the country, where the insured person is regular residing;

- active development of travel infrastructure in frontier regions;

- activation of work immigration;

- liberalization of legal regulatory sphere, which stipulate immigration processes in the countries alongside with the appearance of international organizations.

Results of comprehension of pharmaceutical market as a modern innovative integrated activity in Healthcare System are shown in Tables 2 [23].

Table 2. Pharmaceutical tourism as an essential trend of increasing the level of accessibility of pharmaceutical provision of the population*

\begin{tabular}{|c|c|}
\hline \multicolumn{2}{|c|}{ Parameters of medical tourism analysis } \\
\hline \multicolumn{2}{|c|}{ Definition of the notion "Pharmaceutical Tourism" } \\
\hline \multicolumn{2}{|c|}{$\begin{array}{l}\text { Pharmaceutical tourism (pharmaceutical tourism, pharmacy tourism) - is a set of measures aimed a } \\
\text { meeting the needs of the population in accessible pharmaceutical aid and service outside the region of } \\
\text { consumer's regular place of residence or a country in general. Pharmaceutical tourism, as medical tourism, is } \\
\text { a result of absence of unequal access of different layers of population from any region of regular place of } \\
\text { residence or a country to efficient drugs, pharmaceutical aid and medical aid in general. Pharmaceutical } \\
\text { tourism is definitely related to the notion of physical and social-economic accessibility of drugs [22] }\end{array}$} \\
\hline \multicolumn{2}{|c|}{ Institutional components of organization of measures in pharmaceutical tourism in Healthcare System } \\
\hline \multicolumn{2}{|c|}{ Subject } \\
\hline \multicolumn{2}{|c|}{$\begin{array}{l}\text { Health, life and its proper quality under the conditions of existing resource provision of government and } \\
\text { consumers of medical aid, pharmaceutical aid and the appropriate services in HS. }\end{array}$} \\
\hline \multicolumn{2}{|l|}{ Objects } \\
\hline $\begin{array}{l}\text { Government authorities, which are responsible for } \\
\text { regulation of medical and pharmaceutical activity in } \\
\text { the country, control over their quality, assessment of } \\
\text { risks and perspectives of development in the future. } \\
\text { Pharmaceutical companies, healthcare institutions and } \\
\text { pharmacies of different form of ownership and } \\
\text { economic activity, insurance companies, humanitarian } \\
\text { and social organizations, travel agents etc. }\end{array}$ & $\begin{array}{l}\text { Consumers of pharmaceutical and medical services, } \\
\text { medical and pharmaceutical specialists, representatives of } \\
\text { pharmaceutical companies, humanitarian and social funds } \\
\text { or organizations, insurance agents, travel agents etc. }\end{array}$ \\
\hline \multicolumn{2}{|c|}{ Classification of Pharmaceutical tourism by criteria } \\
\hline \multicolumn{2}{|c|}{ 1.Location } \\
\hline $\begin{array}{l}\text { Internal pharmaceutical tourism stands as a set of } \\
\text { measures focused on getting efficient } \\
\text { pharmaceutical aid and pharmaceutical services } \\
\text { within the country, in which a consumer is regular } \\
\text { residing, but in another administrative area, region, } \\
\text { where he lives. }\end{array}$ & $\begin{array}{l}\text { External pharmaceutical tourism means crossing the } \\
\text { border of the country by the future consumers, where } \\
\text { they are regular residing in order to get necessary } \\
\text { efficient pharmaceutical aid and a number of } \\
\text { pharmaceutical services. }\end{array}$ \\
\hline
\end{tabular}


Continuation of table 2

\begin{tabular}{|c|c|}
\hline \multicolumn{2}{|c|}{ 2.Form of organization } \\
\hline Group & Individual \\
\hline $\begin{array}{l}\text { It means organization of a group tour of physical } \\
\text { entities outside the region of regular residence or a } \\
\text { country at their own expenses or at the expenses of } \\
\text { social and insurance funds in order to buy essential } \\
\text { drugs at a reasonable price or those drugs, which are } \\
\text { not available at the internal pharmaceutical market. } \\
\text { Group forms of pharmaceutical tourism are connected } \\
\text { with humanitarian, volunteer and insurance companies, } \\
\text { which deal with the programs of group (corporate) } \\
\text { medical insurance. Group pharmaceutical tourism can } \\
\text { be organized by an employer, if the above-stated } \\
\text { regulations are stipulated in the contract. }\end{array}$ & $\begin{array}{l}\text { Physical entity or his representative in order to buy } \\
\text { essential drugs at a reasonable price or those drugs, } \\
\text { which are not available at the internal pharmaceutical } \\
\text { market, is crossing the border of another country or his } \\
\text { regular place of residence at his own expenses. }\end{array}$ \\
\hline \multicolumn{2}{|l|}{ Functions } \\
\hline 1. Government and society in general & $\begin{array}{l}\text { 2. System of pharmaceutical provision of the } \\
\text { population and Healthcare System in general }\end{array}$ \\
\hline $\begin{array}{l}\text { - social (contributes to the development of efficient } \\
\text { relations between separate groups of population or } \\
\text { patients, who are residing in frontier areas or in } \\
\text { neighboring countries in general); } \\
\text { - humanistic (an opportunity of effective sale } \\
\text { thanks to pharmaceutical tourism humanistic } \\
\text { potential of modern healthcare system in the sphere } \\
\text { free option of the form and methods of saving your } \\
\text { own health and life under the conditions of existing } \\
\text { resource provision and personal savings); } \\
\text { - stimulating (contributes to the development of } \\
\text { the country pharmaceutical network, which visit } \\
\text { citizens from neighboring countries to buy drugs } \\
\text { and to get pharmaceutical aid and pharmaceutical } \\
\text { services, to increase the level of staff qualification, } \\
\text { which must meet international procedures and } \\
\text { requirements. Moreover, pharmaceutical tourism } \\
\text { allows efficiently develop proper travel and social } \\
\text { infrastructure in the country); } \\
\text { - foreign-economic (pharmaceutical tourism } \\
\text { contributes to the development of the process of } \\
\text { globalization of national economics and development } \\
\text { of more efficient ways of cooperation between } \\
\text { governments of countries that border with each other } \\
\text { focusing on implementation of more rational modes of } \\
\text { relations between business entities in HS) }\end{array}$ & $\begin{array}{l}\text { - medical-pharmaceutical (increase of the level of } \\
\text { efficiency of services provided to the population in case } \\
\text { of loss of health or temporary disability); } \\
\text { - social-economic (increase of the level of physical } \\
\text { and social-economic accessibility of drugs and } \\
\text { pharmaceutical aid in general by separate groups or } \\
\text { patients, who because of a numerous facts cannot afford } \\
\text { to buy and to consume essential drugs); } \\
\text { - market (extends drugs sales markets and contributes } \\
\text { to the growth of competition at the internal } \\
\text { pharmaceutical market); } \\
\text { - informational (increases level of consumers } \\
\text { awareness of new drugs, pharmaceutical services, } \\
\text { which are sold in the country etc.) }\end{array}$ \\
\hline
\end{tabular}

Note: $-*$ (individual research)

As we see, the appearance of pharmaceutical tourism, as a modern phenomenon in Healthcare System and travel activity, is an objective phenomenon. Its appearance was defined by the whole range of factors, among which, to our mind, is physical inaccessibility of essential drugs, and in case of unequal access to pharmaceutical aid of some layers of population it is the result of the existence of inefficient mechanisms of compensation (reimbursement) of the cost of drugs in the country (index of social-economic accessibility).

Thus, reviewing pharmaceutical tourism from different perspectives, we can state that the above-mentioned phenomenon has a dualistic nature. From one point of view, pharmaceutical tourism may be regarded as a negative social-economic phenomenon, which is observed in the countries with improper mechanism of government pricing regulation for drugs, insufficient level of services qualification, which are provided by pharmacies and in the pharmaceutical organization in general, and as well as irregular division of resources between different layers of population and active process of globalization in Healthcare System. For example, in such economically-developed countries as the USA and Canada the government has already started to review a social phenomenon, which is called «Snow birds» in mass media $[24,25]$. In early autumn numerous groups of elderly people, who cannot 
afford to buy remedies against chronic diseases in the country they live, go to Mexico in large numbers to get medical, dental and pharmaceutical aid $[18,24]$. That is, pharmaceutical tourism can be regarded as a consequence of unequal division of resources between different layers of population and active process of globalization, in particular in Healthcare System and system of pharmaceutical provision of population. From the other point of view, pharmaceutical tourism appears as the most powerful mechanism, which effective realization promotes the development of international relations and allows the population to get accessible and efficient drugs, which are not available for them in the country because of some physical or social-economic reasons.

At the end of the research we have to determine the following. By all means, effective realization of pharmaceutical tourism is impossible without an active participation of government authorities, who must promote further development of neighboring relations between different countries, and at the same time to improve forms and methods of government regulation of drugs and pharmaceutical aid accessibility for the population. Moreover, taking into account an integrating character of such activity as pharmaceutical tourism, it is necessary to develop mutual programs between travel, public organizations, from one hand, and medical and pharmaceutical, from the other hand.

\section{Conclusions.}

1. By using data taken from references, we can state that medical tourism appears as a modern activity, which is characterized by an integral character and has deep historic roots. One of the oldest forms of medical tourism is recreational tourism. At the beginning of XXI century there has been formed a ramous infrastructure of medical tourism with international centers that provide relevant services and allow efficiently and quickly satisfy the needs of the population in accessible medical aid and pharmaceutical aid.

2. According to the summary, we have outlined the preconditions of active development of medical tourism as an integral activity in modern Healthcare System, which had been observed at the crossroads of centuries (XX-XXI centuries). Moreover, we have submitted the existing classification of medical tourism by different categories.

3. By the results of studying the influence of tendencies towards the increase of globalization and at the same time - fragmentation (acceleration of centrifugal processes of progress in different countries by the levels of consumption, government warranties of supporting physical and socialeconomic accessibility of pharmaceutical aid and drugs, in particular an access to innovative drugs, medicines etc.) in modern Healthcare System, we can find the facts that substantiate the necessity to separate pharmaceutical tourism as an integral activity, which purpose is to increase accessibility and quality of pharmaceutical aid and pharmaceutical services by different layers of population outside their regular place of residence.

4. We have determined the main preconditions for pharmaceutical tourism separation as an independent area of Healthcare System, which has an integral character. We have outlined institutional components (subject, objects, forms of organization), functions, which can be implemented on two levels: government and society; system of pharmaceutical provision of population and Healthcare System in general).

5. We have substantiated the dualistic character of pharmaceutical tourism as a modern area in Healthcare System. Thus, from one hand, pharmaceutical tourism develops as a result of a wide range of factors, which causes a low physical and social-economic access of drugs and pharmaceutical aid and the provision of pharmaceutical aid to the population of Ukraine. From the other hand, pharmaceutical tourism is formed thanks to the objective strive of an active part of the society for getting pharmaceutical aid and pharmaceutical services on a more qualitative and accessible level within a shorter period of time than they can be ensured by the government or social institutions in the countries, where consumers of services are regular residing.

6. It has been confirmed that pharmaceutical tourism contributes to the development of international, political, social-economic, ethnic cultural and humanistic relations with different countries of the world, which is extremely important for the world community under the conditions of increase of tendencies towards globalization.

7. Taking into account modern tendencies towards globalization of national economics, improper mechanisms of government regulation of the level of pharmaceutical aid accessibility, increase of the gap between different countries and groups of people or patients in the resource provision of proper services in Healthcare System, a tendency towards the development of medical tourism and pharmaceutical tourism will continue in the future. The above-mentioned stipulates the necessity to develop a complex program of assistance of pharmaceutical tourism in Ukraine. 


\section{REFERENCES}

1. Devon Herrick. Shopping for Drugs: 2007. Center for Policy Analysis NCPA Policy Report Vol. 293 Nov. 2006. Available from: http://www.ncpathinktank.org/pdfs/st293.pdf.

2. Tanner L. Hudson. An Interdisciplinary Analysis of Medical Tourism. Journal of Excellence in Integrated Writing Courses at Wright State. 2017. Vol. №4. P. 64-74.

3. Danial E. Baker Has the Time Come for «Medication Tourism»? Hosp Pharm. 2014. Vol. 49(11). P. 99-1000.

4. Lvillo J. P., Lal L. Pilot study of a survey of U.S. residents purchasing medications in Mexico: demographics, reasons, and types of medications purchased. Clinical Therapeutics. 2003. Vol. 25(2). P. 561-577.

5. Гнедик Е. Правовое регулирование медицинского туризма как вида экономической деятельности. Административная и криминальная юстиция. 2017. Т. 4, №81. С. 59-65.

6. Поворозник Н. Ю. Международный медицинский туризм в формировании глобального сегмента медицинских услуг. Вестник социально-экономических исследований: сб. науч. трудов; под ред. М. И. Зверякова (глав. ред.) и др. Одесса: Одесский национальный экономический университет. 2017. № 2-3. - С. 16-24.

7. Романів О. Географія медичного туризму. Часопис сочіально-економічної географії. 2010. Т. 8, №1. C. $79-84$.

8. Панфілова Г.Л. Фармацевтична допомога як історична, нормативно-правова та соціальноекономічна категорія в системі охорони здоров'я й фармацевтичному забезпеченні населення. Актуальні питання фармацевтичної і медичної науки та практики. 2014. Т.2, №15. С. 89-98.

9. Marc Fetscherin, Renee-Marie Stephano. The Medical Tourism Index: Scale Development and Validation. Tourism Management. 2016. Vol. 52. P. 539-556.

10. Баєв В.В. Сучасні тенденції розвитку медичного туризму в Україні. Агросвіт. 2015. № 7. С. 35-38.

11. Тернова С. Медичний туризм в Україні: можливлості VS реальність. URL: https://www.vz.kiev.ua/medychnyj-turyzm-v-ukrayini-mozhlyvosti-vs-realnist/.

12. By Jeffrey Segal. Is «Pharmaceutical Tourism» Just Around the Corner? By Jeffrey Segal. General Surgery News. Okt. 2008. P. 44-45.

13. Kelly L. Karlage, Stephen J. Franklin, Whe Christina Mufich, Kristen J. Goetz et al. Comparative evaluation of pharmaceutical products obtained in Mexico: augmenting existing scientific data. Drug Development and Industrial Pharmacy. 2012. Vol. 38 (7). P. 808-814.

14. Meira Nocella, Emily Kilber, Brittney Witmer. A Comparison of Pharmaceutical Product Performance of Albuterol Inhalers Available in the United States and Those Obtained in a Mexican Border Town. Journal of Pharmacy Technology. July 2015. URL: https://journals.sagepub.com/doi/abs/10.1177/8755122515595052.

15. McKeithan E. K., Shepherd M. D. Pharmaceutical products declared by U.S. residents on returning to the United States from Mexico. Clinical Therapeutics. 1996. Vol. 18(6). P. 1242-1251.

16. Немченко А.С., Косяченко К.Л., Немченко О.А. Ціноутворення на лікарські засоби: монографія. (2ге вид., доп. та перероб.). Х.: Вид-во ФОП Вировець А.П. Видавнича група «Апостроф». 2012.304 с.

17. Haque M. Essential Medicine Utilization and Situation in Selected Ten Developing Countries: A Compendious Audit. J Int Soc Prev Community Dent. 2017. Vol. №7(4). P.147-160.

18. Jennifer Miller-Thayer. Health Migration: Crossing Borders for Affordable Health Care. Field Actions Science Reports. The journal of field actions. 2010. Special Issue 2. Retrieved from http://journals.openedition.org/factsreports/503.

19. Українці масово їдуть в Європу за ліками: навіть там дешевше. URL: https://znaj.ua/society/206575ukrajinci-masovo-jidut-v-yevropu-za-likami-navit-tam-deshevshe.

20. В аптеку - за кордон: чому ліки в Україні коштують дорожче, ніж в Польщі. URL: https://uk.etcetera.media/farmturi-ukrayintsiv-chomu-liki-v-polshhi-i-turechchini-v-kilka-raziv-deshevshi.html.

21. Стоимость лекарственных препаратов в странах https://www.insure.travel/articles/stoimost-lekarstvennyh-preparatov-v-stranah-mira.html.

22. Дмитрик Е. Фармрынок США: текущие тенденции и прогноз расходов на лекарственные средства до 2023. Еженедельник «Аптека». 2019. T. 30 №. 1201. URL: https://www.apteka.ua/article/512724.

23. Самборський О. С., Слободянюк М. М. Організація фармацевтичного туризму як сучасного напрямку підвищення рівня фізичної та соціально-економічної доступності ліків в світі. World Science. Sept. 2019. 9(49), Vol.2. P. 53 - 59. DOI: https://doi.org/10.31435/rsglobal_ws/30092019/6711

24. Kelly L., Karlage and Paul B. Myrdal. Mexico and the United States: A Case Study. Drug Development and Industrial Pharmacy. 2005. Vol. $31 \quad$ (10). P. 993-1000. URL: https://www.tandfonline.com/doi/abs/10.1080/03639040500306245.

25. Landeck Michael, Cecilia Garza. Utilization of Physician Health Care Services in Mexico by U.S. Hispanic Border Residents. Health Marketing Quarterly.2002. Vol. 20. P. 3-16. 